\title{
PAPER \\ Economic Development
}

Lecturer :

Dr. Yulhendri, S.Pd., M.Si

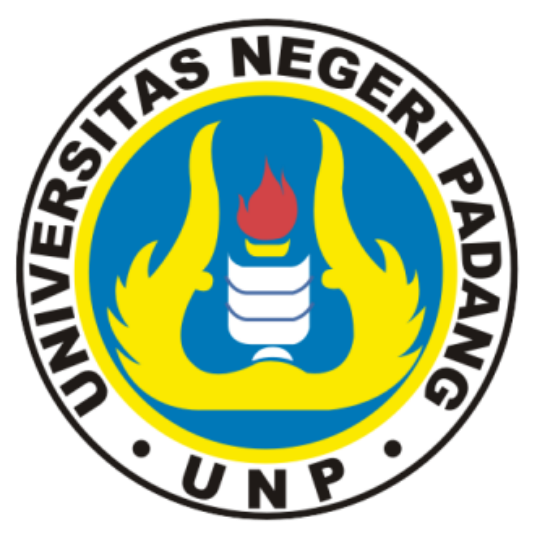

By :

Diana Annisa (17053086)

\section{ECONOMIC EDUCATION UNIVERSITAS NEGERI PADANG 2019}




\section{Foreword}

Thank you for the presence of Allah S.W.T who has given His grace and grace, so that I can finish this paper well.

I made this paper in order to fulfill the task of the Development Economics Course. And I would like to thank our lecturers, Dr. Yulhendri, S.Pd., M.Si who have provided guidance, suggestions, ideas and opportunities for us to explore information about Economic Development in depth.

I realize that the paper made is very far from perfection, therefore I request criticism and suggestions from all parties that are constructive, and become a new learning for the author himself to achieve the perfection of this paper.

Finally, I express my gratitude and hope this paper can provide information and be useful for the development of science for all of us.

Padang, May 2019

Author 


\section{CHAPTER I}

\section{PRELIMINARY}

\section{A. Background}

The main problems in economic development are increasing economic growth, eliminating poverty and eliminating poverty. In some destination countries it is sometimes a dilemma between emphasizing economic growth or reducing inequality in income distribution (Deininger and Olinto, 2000). High growth does not necessarily guarantee that the inequality of income distribution will be low.

Poverty and income inequality are two things that are being intensely emphasized by the government's growth. Inequality is closely related to poverty because fundamentally inequality is an indicator of relative poverty, namely the gap between the rich and the poor. The low level of inequality, or the more even distribution of income, is certainly one of the important agendas of economic development.

To measure economic inequality can be seen using the Gini ratio. Gini ratio is an indicator of income distribution level indicated by a coefficient of zero to one, which means the higher the coefficient, the more uneven distribution of income of the population.

\section{B. Objectives and Benefits}

The purpose of making this paper is:

1. In order to understand the things that cause economic growth without being followed by an increase in income distribution in Indonesia.

2. In order to understand the Source of economic inequality, especially in Indonesia.

3. In order to find out what efforts are being made by the government to reduce the level of development inequality.

4. In order to find out which is stronger the desire to get group and personal benefits than the greater national desire.

5. To find out the relationship between population and income distribution.

6. In order to know the distribution of land ownership.

The benefits of making this paper are:

1. Providing new and deeper insights (knowledge) regarding economic growth in Indonesia.

2. Add value to the Development Economics Course. 


\section{CHAPTER II}

\section{DISCUSSION}

\section{Things that cause economic growth without being followed by an increase in income distribution in Indonesia.}

Economic growth is a process of increasing per capita output in the long term. Economic growth is one indicator of the success of development. Thus the increasing economic growth usually increases the welfare of society, although there are still other indicators, namely the distribution of income. While economic development is an effort to increase per capita income by processing potential economic forces into the real economy through investment, increasing knowledge, increasing skills, using technology, adding management skills and organizing.

Economic growth is also related to the increase in "per capita output". In this sense the theory must include theories about GDP growth and theories about population growth. Because only those two aspects are explained, the development of per capita output can also be explained. Then the third aspect is economic growth in a long-term perspective, that is, if for a long period of time the per capita output shows an increasing tendency.

The state of income distribution in Indonesia since 1970 can be said not to improve, this is caused by many factors, including the First production factor market (input market) which is the increase in labor supply which results in excess labor, low labor wages and limited employment opportunities in urban areas resulting in unemployment and urban slums.

Second, land ownership. Land distribution is the main determinant of the extent of poverty and income distribution.

Third, Ownership of human capital (Human Capital). Humans are actually active capital in development, increasing productivity and benefits of human capital is largely determined by the skills and education possessed by individuals. The ability of a nation's human capital is aggregately determined by the level of the workforce and the education of its population.

The increasing contribution of the industrial, service and trade sectors in the formation of GDP as a process of economic transformation does not have a direct influence on better income distribution in Indonesia.

The increase in gross domestic product sourced from the industrial, service and trade sectors will have a direct influence on per capita income in Indonesia.

The process of economic development that occurs in each country produces a circular relationship that causes the rich to get richer and the poor get poorer. Inequality of regional distribution and international distribution, can hamper economic growth which has an impact on the smaller income per capita. 
The problem of income distribution contains two aspects. The first aspect is how to increase the level of welfare of those who are still below the poverty line, while the second aspect is overall income distribution in terms of narrowing the difference in income levels between residents or households. The distribution of national income reflects the even distribution of products of a country among the population.

From Todaro's quote, it can be concluded that:

1) Equitable income will lead to increased public access to credit, insurance, and school funding

2) Equity will improve living standards and work productivity

3) Equity can lead to increased public purchasing power

4) Equity will also increase the active participation of the community in development.

With good distribution of income distribution, it can reduce socio-economic problems, and can also be used as capital to accelerate the process of economic growth in Indonesia.

The relationship between economic growth and income distribution needs attention. A very important problem is identifying pathways that connect economic growth with income distribution. This must be done to produce policies that can encourage economic growth with equal distribution of income.

Which affects the high and low population growth is not the level of income per capita or aggregate income but how the income is distributed. Population growth is not a problem but an important element in economic development.

\section{Source of economic inequality, especially in Indonesia}

Rapid economic growth is the main cause of the increasing inequality that has occurred in Indonesia. Inequality occurs because of rapid economic growth and is not followed by technological and educational equity. Other causes are lack of access to land, capital and markets, high levels of urbanization and imbalances between formal and non-formal workers. The lack of access to land and capital will cause people who want to produce to be hampered due to many rules such as tight credit with high interest rates. In Indonesia non-formal workers are far more than formal workers, high urbanization from village to city will cause the supply of labor in the city to increase sharply even though the formal sector in the city is not necessarily able to absorb all the labor supply, and ultimately cause unemployment in the city will increase and then poverty will also increase and income inequality will occur.

Inequality consists of 2 types, first the income distribution between groups as measured by the Gini index and how many "economic cakes" are enjoyed by $40 \%$ of the lowest income groups. Increased inequality is measured by the widening income distribution as seen from the Gini ratio which increased 0.29 in 2002 and 0.35 in the year. Second, inequality between regions which is important to be examined again due to the gravity of Indonesia's economic activity which still tends to be geographically concentrated into the western part of Indonesia. 


\section{Source of economic inequality in Indonesia}

Many types of inequality that occur in Indonesia such as economic savings in income, wealth and consumption. Opportunity inequality, when not everyone has access to equal opportunities in life. There are also factors beyond the control of individuals that have the potential to influence the phase of life later, such as: where you were born, how educated or the richness of your parents, and what access to public services are obtained when you grow up.

Getting a healthy start in life and quality education is a basic prerequisite for getting a good job and getting a decent life in the future.

Other factors beyond the control of individuals that can affect income, living standards, and inequality include: policies from the government, such as restrictions on food imports which lead to increased living costs of most poor people, or patterns of taxation and allocation of government spending that does not collect and distribute sufficient resources for the poor or those who do not have equal access.

High levels of inequality can slow economic growth, while other more equal countries can grow faster. High levels of inequality can reduce economic growth for the entire community.

High levels of inequality will cause social impacts that can exacerbate conflict. When the community is aware of the existence of a gap in income and wealth, the potential for social tensions and unreliability is very likely to occur and cause conflict.

There are several factors that cause economic inequality in Indonesia. First, it is difficult for people to access basic services, such as health, education, water, and sanitation. When people do not have access to education, sanitation and housing, it is certain that they will be left far behind. Second, inequality in the quality of work. People who are less skilled or who do not have skills in certain fields will be trapped in jobs with low productivity and wages. Third, inequality of income and assets. The imbalance of income causes wealth to be focused on a small group of people. Fourth, the absence of safety nets during shocks, or the absence of social security.

The high economic inequality has resulted in low income groups unable to access basic needs and services such as education, health and food. This will adversely affect the community and slow down the human development process. High inequality can have a negative impact on people's quality of life, social cohesion, and economic growth. Inequality in Indonesia is closely related to inequality, both in accessing economic opportunities and public services.

\section{Causes of inequality in Indonesia, namely:}

1) Market fundamentalism that encourages rich people to take the greatest advantage of economic growth.

2) Low wages that make the lower class unable to lift themselves from the brink of poverty. 
3) Increased political capture, namely rich people are able to take advantage of changing the rules that can benefit them.

4) Inequality of access between rural and urban areas towards infrastructure.

5) Tax systems that fail to play an important role in distributing wealth.

6) Gender inequality.

\section{Government efforts to reduce the level of development inequality}

Economic development is a business that must always be carried out, which aims to increase national income (gross national product), then divide the national income to citizens fairly, the progress of the industrial sector to absorb a high workforce and reduce unemployment and poverty (Todaro , 2004). However, economic progress alone is not enough, analysis and policy makers develop development in the social dimension such as developed by the UNDP (United Nation Development Program) with a measure of human development with several indicators including literacy, education level, condition and quality of health (UNDP, 2004).

The main requirements for the life of the social community are the existence of a relationship or interaction between community members, as well as the existence of development that can influence the emergence of social change. Social interaction and social development that do not work should also lead to social inequality which results in the emergence of many social problems. The problem of social inequality is common in various countries, including Indonesia. Although economic development in Indonesia is quite good, the problem of social inequality in the community is still high. Social inequality is one of the major tasks faced by the Indonesian government in an effort to improve people's welfare. In general, many efforts can be made to reduce the level of social inequality in society, the Indonesian government has also tried to reduce inequality that occurs, but to overcome social inequality cannot be done in a short time, or requires a long period of time and a clear strategy and detailed to get maximum results.

Social inequality is a social problem where there is injustice in society due to the uneven development process, especially in the process of economic growth. Some examples of inequality that occur, including:

\section{a. Discrimination}

The impact of discrimination is the emergence of a sense of injustice among citizens, such as: racial discrimination, gender discrimination, religious discrimination, and many other discrimination.

\section{b. Economic Domination}

In Indonesia, the example of social inequality that is most easily seen is economic dominance. This condition is caused by an uneven economic development process, where the Java region dominates the economy while other regions such as the Eastern Indonesia Region are still fairly underdeveloped or underdeveloped. 
Factor in the emergence of social inequality

a. Economic factors

The main factor in the emergence of social inequality is economic factors, where uneven economic development will lead to inequality of development in each region differing from one another. In addition to uneven development, differences in quantity of resources and factors of production in a region can also be another factor in social inequality in economic factors.

\section{b. Demographic Conditions}

Each region has different demographic conditions including differences in population, population composition, and population distribution which can also influence the emergence of social inequality in the community.

\section{c. Educational Conditions}

Education is needed for all citizens because development is the main key to development, especially in the development of human resources. Social inequality can be seen from the quality of education, teaching staff, educational facilities, and others. As an example we can see such an imbalance where children in disadvantaged areas have less educational facilities but usually they have high enthusiasm, while children in urban areas have adequate facilities but because of social influences and changes in their social culture actually lack enthusiasm in studying. Moreover, coupled with changes in people's behavior in changing social culture in the global era.

\section{d. Health Factors}

Uneven health facilities in each region can be a factor in the emergence of social inequality in people's lives. In remote areas that are considered to be lagging behind, their health coverage is also inadequate, and inadequate health services are caused by a shortage of medical personnel. Because these conditions affect the level of health and well-being among people, causing social inequality.

There are several factors that allow for social inequality in society, such as failed government policies, lack of attention from the government, and much more.

\section{Efforts to overcome social inequality}

1) Increasing the quality of the population

Diversity possessed in community life can influence the emergence of social inequality. Therefore, efforts to improve the quality of the population are very important to reduce the level of social inequality. Efforts that we can do, namely:

- Improve and improve the quality of education 
- Improve and improve the quality of health facilities both in terms of medical personnel and health services provided

- Creating community group empowerment activities, such as socialization, counseling, and direction to the community

2) Geographic Mobility

Geographic mobility aims to control the population in an area, because geographical mobility is closely related to population movements. This situation is an effort to overcome social inequality through equal distribution of population and equitable development.

\section{3) Creating Job Opportunities}

Creating employment opportunities can avoid social inequality because in regions or countries that have a high population, the number of unemployed people due to lack of employment opportunities is also high. The high number of unemployed and lack of employment opportunities can lead to social inequality in society, therefore we need an effort to create employment opportunities, one of which is by utilizing the conditions in the surrounding environment. Efforts made not only by the government but also by cooperation with the community.

\section{Indonesian Government's Efforts to Overcome Inequality}

There have been several efforts made by the Indonesian government to address social inequality, including:

1) Eradication of malnutrition or stunting

Malnutrition is considered to exacerbate the condition of poverty in Indonesia as an example of the problem of social inequality in the community which must be immediately corrected. The highest cases of malnutrition in Indonesia occur in the eastern regions, and more attention is needed by the government.

\section{2) Distribution of Targeted Social Assistance}

The targeted distribution of social assistance aims to reduce the social inequality that exists in the community due to the presence of regions or communities that lack assistance, but have not yet received the assistance.

\section{3) Increased Job Opportunities}

Economic growth in Indonesia can be said to be quite good and advanced, but economic growth should be supported by an increase in new employment opportunities to reduce unemployment. The government seeks to provide training and education that is tailored to the needs of the labor market and to increase skills and human resources equally.

4) Reducing Wealth Inequality 
This effort is done by rearranging income tax where in Indonesia is still dominated by workers. Whereas personal income such as entrepreneurs, capital owners, has a greater tax obligation than workers, but the implementation is not optimal. This condition has caused social inequality.

5) Creating entrepreneurship en masse

In addition to creating new jobs, the state of poverty and unemployment can be overcome by efforts to create mass entrepreneurship.

\section{What is the stronger desire to get group and personal benefits rather than greater national desires?}

We can see human capital in two perspectives, namely individual or household perspectives and an aggregative or national perspective. In the individual perspective, human capital is a concept in which individual measures and indicators are attached (micro). Human capital is a personal capability in the form of a number of knowledge, leadership, skills, attitudes and with that, they can improve their personal values better.

Meanwhile in national or macro perspectives, economists calculate human capital in the form of the number of people who complete education at a certain level of education such as the number of people completing high school education and tertiary education because by completing high school education above it is assumed that someone will have knowledge and adequate skills to improve themselves and aggregatively these skills are measured in terms of the number of people who complete a particular education.

Education is a systematic effort that can be done to increase the amount of accumulation of human capital in a country. In Indonesia, now it seems that it has become a common awareness so that the political process to produce pro-education policies has begun to appear. This can be seen from the amendments to the 1945 Constitution which require that a minimum of $20 \%$ of the total State Revenue and Expenditure Budget (APBN) must be allocated to the education sector. In developed countries, awareness of the importance of education has already taken place hundreds of years ago compared to us Indonesia.

The basic potential that God gives to humans makes people able to think and always learn as one of their humanitarian tasks. Sociologists and anthropologists share several types of activities and human abilities to adapt, carry out cultural transformation and cultural evolution with the environment including socialization, internalization and enculturation. (Koentjaraningrat, 2002).

Some studies show that there is a relationship between education and the quality of social capital. Because education is a systematic process in which social interactions occur between educators and students, where educators function as facilitators of learning and direct students to learn. Learning is a process of changing attitudes, behavior and knowledge which previously did not know to know, from those who are not good at reading letters to being good at writing, from those who are not good at writing to being good at writing, from being unskilled to being skilled, from being incompetent competent, from those who are not good at 
expressing being good at hearing and being able to receive understanding. Then, the longer the age of students, the higher the level of psychological development and the sooner the students begin to think rationally, can describe, can explain, can think of causation, can give good and bad judgments, black and white, high -low, can compare, and can make choices so that the choice is right, accurate, true, and trustworthy.

The process of education allows humans to have good learning habits, because education will make people accustomed to reading, listening, writing, speaking, analyzing and producing conclusions, making steps and work procedures, can determine which ones must be prioritized and which are ended.

\section{Relationship between population and income distribution}

Through economic growth, living standards improve. Economic growth brings a change. New items are produced, while others are out of fashion. Some believe that growth is a basic goal of society, because growth brings people out of poverty and improves the quality of their lives.

The greater the inequality of income distribution, the more people living below the poverty line. This is because income and economic growth are only enjoyed by some people.

Economic growth cannot provide benefits to the population of a country, if there is an imbalance in income distribution. In economic factors where income is only enjoyed by certain groups, it will cause poverty problems.

According to Adam Smith, available natural resources are the most basic container of community production activities. The amount of natural resources available is the "maximum limit" for the growth of an economy. That is, if the resource has not been fully utilized, the total population and existing capital stock play a role in output growth. However, the output growth will stop if all of these natural resources have been fully utilized. Human resources (population) have a passive role in the process of output growth. That is, the population will adjust to the need for labor from a community.

The population will increase if the prevailing wage rate is higher than the subsistence wage rate. While the wage level itself is determined by the attraction between the strength of demand and supply. The wage rate will be high if the demand for labor grows faster than the supply and vice versa. If the wage rate continues to decline and falls below the subsistence wage level, then the rate of population growth will be negative. At subsistence wage rates, the population is constant.

Economic growth can be achieved by doing specialization or division of labor. Efficiency and productivity do not have to be done by adding resources or changing technology which according to classical theory is a determinant of economic recovery, but enough to do and practice the division of labor (specialization).

The influence of economic growth on income distribution in terms of economic theory can be explained as follows, there are two views on the relationship of economic growth and income 
distribution. One view supports that economic growth has a negative effect on the inequality of income distribution, while other views suggest otherwise. Broadly speaking these two views are:

A view that rejects economic growth has a negative effect on income distribution:

Theory of Karl Mark (1787). Mark argues that economic growth in the early stages of development will increase labor demand. The increase in the wage level of the workforce further influences the increase in the risk of capital towards employment, resulting in a decline in the demand for labor. As a result, problems arise from unemployment and income inequality. In short, economic growth tends to reduce the problem of poverty and income distribution only in the initial stages of development, then the next stage will be the opposite (Irawan, 2002).

The Neo Marxist states that economic growth will always cause a widening gap in inequality between the rich and the poor. This happened because of the accumulation of capital and technological advances which tended to increase the concentration of resource and capital control by the "elite" group of capital rulers. Conversely, non-capital owners will remain in a state of poverty.

\section{Distribution of land ownership}

The relationship between land and agricultural activities has a closely related relationship and causes efforts to improve farmers 'welfare is not enough just through technological and institutional improvements related to the production process, improving farmers' access to land will affect the success of efforts to improve the lives of rural communities as a whole. For example, agricultural land tends to be more limited because it has to compete for various uses, while people working in agriculture in absolute terms continue to grow, causing the owners and control of land to become increasingly narrow. This condition is a result of the accumulation of errors in the implementation of development policies that are not in favor of agriculture, after the issuance of laws and regulations that make it easier for investors to acquire land, including agricultural land and the rights of the indigenous people. The efforts of agrarian reform, with the aim of improving farmers' access to land, need to be initiated by updating various existing regulations or laws. This effort should be carried out simultaneously with the improvement of the database relating to land, because there is still a confusion of data and the many agencies that deal with land issues, this is a major obstacle in implementing agrarian reform in Indonesia. In order for this effort to be carried out it requires polical, comitment from the government and the legislature about the importance of agrarian information in Indonesia.

\section{Understanding Land reform.}

The definition of "land reform" is different from "agrarian reform". One program of "land reform" is the distribution of land or division of land. The definition of "agrarian reform" (agrarian reform) is broader than "Land reform", namely renewal in the structure of control, production structure and structure of supporting services. "Agrarian reform" is actually an 
effort to change or social reform which is done consciously to transform the agrarian structure towards a healthier and more equitable agrarian system for agricultural development and the welfare of the village people.

\section{This "land reform" program includes:}

a. Prohibition of controlling land beyond the limit

b. Prohibition of controlling land in an absentual manner

c. The excess of land ownership and absentual lands can be distributed

d. Arrangement of returning liens that have lasted 7 years or more

e. Reorganization of agricultural products

f. Determination of minimum and maximum limits on agricultural land owned.

The purpose of "land reform" is as follows:

a. Fair land distribution by changing land structure

b. Not revolutionary

c. To strengthen or expand property rights on land

d. To end the system of landlords and eliminate land ownership and control of land by setting minimum limits and maximum land that can be owned.

e. To enhance production and encourage intensive agriculture in mutual cooperation.

\section{Classes of Land Authorities in Indonesia}

- Feudal Government

Kings in Indonesia controlled lands, ordinary people were employed and the results were for kings, nobles. The people work only enough to eat.

- Landlords (land lords)

Landlords in the capitalist government (UK) carried out a system of tax payments called rent (created by Rafles) adjusted to the capabilities of the people regulated by the customary head. The greater the ability to pay taxes, the wider the area occupied, resulting in old landlords. They adhere to the principle that all the lands in the colonies belong to the king of England. Subsequent developments in land tenure were carried out as widely as possible by landlords of Chinese people.

- Society for bout (the development of capitalism)

They turned the agrarian structure into a capitalist by entering the third world. The agrarian structure was created to serve the nations of capitalism, the colonizing nation. 
- After independence (Land Reform)

The third world after sovereignty seeks to carry out agrarian reform which leads to equity and justice by establishing land rights through a "land reform" program. "Land reform" is the distribution of land, the re-establishment of ownership, ownership of land rights. The lands are distributed to poor farmers, cultivators, land workers and so on based on the Basic Agrarian Law No. 5 of 1960 and Law No. 56 of the Republic of Indonesia in 1960 concerning Determination of Agricultural Land Area.

\section{Land Rights}

1. Land tenure rights

According to the State Law, land tenure has the following hierarchies:

1) Land is the right of the nation

The state has the authority to give to its citizens.

2) Land tenure is a state

In Indonesia, before the entry into force of the Agrarian Basic Law No. 5 of 1960 concerning Basic Agrarian Principles the rules applied were "wet agrarianche" 1870 (Aw-S 1870-ss) and "agrarische besluit" (AB-1870-118). Article 1 AB regulates the existence of land in Indonesia, that all land that cannot be proven ownership is owned by the state (state capital) known as the Verklaring principle. This Verklaring principle classifies the rights to colonial government land as follows:

3) Customary rights to land

Ulayat rights are often also called pertuanan rights or limpo rights (in South Sulawesi). Land that is carried out by the people continuously on communal rights, is no longer customary rights but is an individual right which in the long run becomes the right of ownership for generations.

4) Individual rights to land

This right is regulated in Article 16 and Article 20 of Law No. 5 of 1960 concerning Basic Regulations on Agrarian Principles. According to Article 16 paragraph (1) the LoGA consists of:

- Right of ownership.

- Cultivation Rights.

- Building rights.

- Right of Use.

- Rental Rights. 
- Right to Open Land.

- Right to Collect Forest Products

\section{Source of acquisition of land rights and their use.}

Land rights include all rights obtained directly from the state called primary rights and all rights derived from holders of other land rights based on collective agreements, are called secondary rights. Both of these rights generally have equality, where the holder has the right to use the land he controls for himself or to benefit from other people through an agreement in which one party gives secondary rights to the other party. This individual right can be traded and inherited which consists of:

- Primary Rights: Property Rights, Cultivation Rights, Building Use Rights, Use Rights to state land, rights to open forests and others.

- Secondary (temporary) rights, namely mortgage rights, profit sharing rights, lease rights.

- Right of ownership
a. Individual Property

Property rights granted to individuals. Property rights are granted for an unlimited period of time, as long as the ownership rights are still recognized in the framework of the enactment of the LoGA. Based on the provisions of Article 27 of the LoGA, rights to land can be deleted if:

- The land falls to the country:

- Because revocation of rights based on Article 18

- Because of the voluntary submission by the owner

- Because it is abandoned

- Because the provisions of Article 21 paragraph (3) and Article 26 paragraph (2), namely transferring ownership rights to foreigners, Legal Entities other than those determined by the Government are null and void because the law and land fall to the state.

- The land is destroyed.

\section{b. Legal Entity Property}

In principle, legal entities may not have land with ownership rights unless specifically determined by law or other regulations, as determined by Government Regulation Number 38 of 1973, namely: 
$\checkmark$ Banks established by the state.

$\checkmark$ Agricultural cooperative associations established under law Number 79 of 1958.

$\checkmark$ Religious bodies appointed by the minister of agriculture / agrarian after hearing the minister of religion.

$\checkmark$ Social bodies appointed by the minister of agriculture / agrarian after hearing the social minister.

The implementation of the land reform program which intends to use the land as much as possible for the prosperity of the entire Indonesian nation has not been able to be carried out properly because of the interests of landlords or aristocratic groups, so that the former feudal lands and the former Dutch plantations cannot be utilized as well as possible by the people.

Arrangement of ownership rights of land for sale or housing for fishermen on the shores of the coast is still constrained by agrarian regulations which require a minimum distance of 200 meters from the sea edge which is permitted to obtain a certificate. 


\section{CHAPTER III}

\section{COVER}

\section{Conclusion}

Economic growth affects the income distribution in Indonesia. The influence is positive and significant, the contributing factors are subsidies that are misdirected, the low level of education and technology mastery and institutional factors such as "corrupt" institutions and policies that are not pro-people.

Economic growth is one indicator of the success of development. Thus the increasing economic growth usually increases the welfare of society, although there are still other indicators, namely the distribution of income. While economic development is an effort to increase per capita income by processing potential economic forces into the real economy through investment, increasing knowledge, increasing skills, using technology, adding management skills and organizing. 


\section{Bibliography}

Yulhendri. 2009. Pembangunan Ekonomi. Padang: UNP Press.

Yulhendri. 2013. Pembangunan Modal Manusia dan Modal Sosial. Padang : PT NAGAKUSUMA MEDIA KREATIF.

Arifianto, Setiyono. 2013. Pengaruh Pertumbuhan Ekonomi Terhadap Distribusi Pendapatan Di Indonesia. (Online),

https://www.google.com/search?q=PENGARUH+PERTUMBUHAN+EKONOMI +TERHADAP+DISTRIBUSI+PENDAPATAN+DI+INDONESIA\&oq=PENGAR UH+PERTUMBUHAN+EKONOMI+TERHADAP+DISTRIBUSI+PENDAPATA $\mathrm{N}+\mathrm{DI}+\mathrm{INDONESIA \& aqs}=$ chrome..69i57.1245j0j4\&sourceid $=$ chrome\&ie $=\mathrm{UTF}-8$ (Diakses tanggal 12 Mei 2019)

Mistar.Distribusi dan Hak Kepemilikan Atas Tanah. (Online) https://www.academia.edu/29521371/Distribusi_dan_hak_kepemilikan_atas_tanah 